\title{
REFLECTING ON LAW, MORALITY AND COMMUNAL MORES (with particular reference to the protection of pre-natal life)
}

\author{
Lourens M. du Plessis \\ Department of Public Law \\ University of Stellenbosch \\ STELLENBOSCH
}

\begin{abstract}
This article deals with the relationship between law, morality and communal mores with particular reference to the protection of pre-natal life in South Africa. It is argued that personal, moral choice influences communal mores and that these mores can, in tum, be transformed into legal noms, thus becoming part of the legal system.

It is pointed out that South African law lends insufficient protection to foetal life - especially in situations where it stands to be destroyed as a result of abortion. It is then suggested that the legal subjectivity of the foetus should be recognized and that every application for an abortion should be heard by a court of law or, altematively, a specialist tribunal. The foetus should be represented at these proceedings by a curator ad litem.

It is finally argued that the proposed arrangement will not unduly encroach on the moral freedom of the individual and that personal, moral choice and communal mores will still be of decisive significance in regulating 'bio-ethical' morality.
\end{abstract}

\section{INTRODUCTORY REMARKS}

Law, morality and social interaction (from which communal mores emanate) are modes of being (and experience), the very essence of which cannot be defined, but is perceived intuitively. 1 What can be defined though, are the beings themselves: a tree,

\footnotetext{
${ }^{1}$ H.G. Stoker (1967:239-243) is of the opinion that the diaphanerotic method of intuitive perception is best suited to help one gain insight into the essential nature of something. It is a phenomenological method of 'looking into' (i.c. examining and 'seeing') the innermost nature (or root) of something, in casu a mode of existence. That which is examined, say for instance A, 'reveals itself' to the person who is examining, provided that non-As are, for the time being functionally abandoned from the view of him or her who examines. There must be, as Stoker would put it, a "selektief-relevante afsien van" (i.e. a selectively relevant abandonment of) non-As.
}

Herman Dooyeweerd (1969:472-485 and Encyclopaedie 3-4) also opts for intuition as an active 
the State, legal norms, moral conduct etc. The exception here is the human being: a human being him- or herself cannot reflect on 'being human' in its totality and can therefore not acquire the bird's-eye view needed to define it. At any rate definition, even in instances where it is feasible, by and large remains an inadequate method to describe any being.

The main focus of this paper are modes of being (or modalities) - not the beings themselves. The topic that will be reflected on is, however, of vital importance to human beings. It involves crucial issues (of life and death) which ultimately transcend modality.

A theoretical model explaining the relationship between law, morality and communal mores will first be developed and will then be applied to matters related to the legal protection of pre-natal life.

\section{LAW}

The law protects. But it does more than that: it secures, it vouches for. Law as a distinctive mode of existence is security-in-office. The virtually untranslatable Afrikaans says it better: ampsgeborgenheid. Security-in-office and/or ampsgeborgenheid cannot be definitions of the law. They are but lingual expressions - in the form of catchwords - bringing to light something of the very nature or the uniqueness of law as a mode of being: they put into words a 'given' or a 'phenomenon' which enters the human horizon of experience through intuitive cognition or perception.

Law in its uniqueness cannot be defined because definition describes $A$ in terms of $X$, $\mathrm{Y}$ and $\mathrm{Z}$ which are non-As: it combines $\mathrm{X}, \mathrm{Y}$ and $\mathrm{Z}$ into a higher unity and arranges them in an orderly way so as to shed light on or 'say something about' $A$. However, the really distinctive nature of $A$ ( $A$ in its uniqueness) cannot be captured in terms of (the higher unity or an orderly arrangement of) non-As.

agent in gaining knowledge of the innermost nature (or meaning-kemel, as he would have it) of modes of being (or modalities). He points out that the human intuition is not merely 'something psychological' but that - as part of the temporal depth structure of human experience - it also has definite analytical and/or theoretical significance.

The method that I use to come to knowledge of the very nature of modes of being (such as law, morality and communal morality) is an adaptation of the diaphanerotic method of Stokcr and of Dooyeweerd's view of the theoretical function of human intuition. For a more comprehensive exposition see Du Plessis (1978:640-643). 


\subsection{Security-in-office implies:}

* Human persons with authenticated status, i.e. people vouched for.

* Norms or rules which authenticate.

* A comprehensive order within which status and normativity interact.

Status, nomativity (or regularity) and order interact as correlates: the one implies the other(s) and it is only as interdependents that they are incarnated in security-in-office which provides the basis for their interaction.

What has thus far been stated can, from an analytic angle, be unraveled as follows:

The law

* provides elbowroom or living-space for the human person-in-office;

- determines the bounds of such elbowroom vis a-vis that of others, and

* vouches for the position, the foothold, of the person-in-office.

'Office' is to be understood in a comprehensive and 'provide' and 'vouch' in a basic or a fundamental sense:

- A person's office encompasses everything relative to his or her position as someone who, in this world, exists for a certain purpose, has a definite role to play (albeit in various capacities) and needs elbowroom as well as 'equipment' to do so. 'Office' therefore coheres with (and implies) status - and vice versa.

John Rawls (1972:236) captures the basic or fundamental nature of law as a socialphenomenon as follows: "... [L]aw defines the basic structure within which the pursuit of all other activities takes place."

Coercion can, if and when necessary, be used to maintain law. Coercion in relation to the law is, however, as a rule latent - i.e. coercion-in-store - and should, ideally speaking, only be actuated once personal status or the legal order itself comes under threat, or in instances of reparation. 


\section{LAW AND MORALITY}

Law differs in principle from morality as the voluntary assumption of responsibility (for others).

* The moral counterpart of legal status is individual disposition or inclination,

* that of normative legal authentication, interpersonal persuasion and

* that of legal order personal reliability or troth.

Law tends to be official, external, objective and formal. Morality is dispositional, internal, subjective and informal. Law has compulsion in store; morality operates through conscience and conviction. However, law and morality do not exist in worlds apart. Actually they do not constitute two different spheres; they are much rather impetuses to two different kinds of (social) strategy - the one inclining more to compulsion, the other to persuasion. Coercion is the bottom line of law-as-strategy; personal choice is that of morality.

A legal strategy is appropriate in instances where human interests in need of 'basic' or 'official' protection are at stake; a moral strategy in instances where personal choice is not likely to effect the 'official basis' of being (purposefully) human, and yet expresses the (voluntary) assumption of responsibility for others.

The choice of Mr. A and Ms. B to practice 'free love' is, if they happen to be consenting adults, a moral choice, which neither erodes nor improves their basic status as legal subjects. In certain instances, however, extra-matrimonial sexual intercourse warrants (and even necessitates) legal intervention because interests susceptible to legal protection are at stake:

* Should Mr. A have sexual intercourse with Ms. B without her consent, his conduct constitutes rape. The law will most definitely intervene. Not only is the integrity of Ms. B's body - as a legally protected interest - violated by this unwarranted intrusion, but public interest comes under threat as well: the public at large is entitled to legal protection against rapists (such as A) even though (for the time being) $B$ as individual has been the only victim of A. Public penance (in the form of punishment for his crime) is therefore legally incumbent upon $A$.

- If an illegitimate child, $C$, is born from the affair of $A$ and $B$, the law will vouch for the interests of $\mathrm{C}$ by, for instance, requiring from $\mathrm{A}$ as the natural father of the 
child, to maintain her. The free moral choice of $A$ and $B$ does not, in this instance, obviate A's legal responsibility towards $\mathrm{C}$.

* In the last example Mr. A is married. The law protects the integrity of matrimony against intrusion by third parties: consortium is a legal interest. Mrs. A can therefore claim damages from Ms. B. Furthermore, should Mrs. A institute divorce proceedings against her unfaithful husband, the law provides that Mr. A's act of adultery with Ms. B must be taken into account in order to determine whether his marriage to Mrs. A has broken down irretrievably. If Mrs. A can prove such breakdown, she is entitled to a divorce.

\section{COMMUNAL MORES}

A basic question remains: Who determines what 'interests in need of basic or official (i.e. legal) protection' are - and how is it done? I have already alluded to the fact that law and morality do not exist in worlds apart. As a matter of fact, the interaction between them becomes most visible in what I prefer to call communal mores. These mores reflect, at least in part, a communis opinio populis (Afrikaans: gemeenskapsopvatting) as to the assumption of responsibility, though not voluntary (as in the case of morality), but by mutual agreement. This strategy does not allow for a legal sanction which (can) compel (if necessary). Mutual agreement is much rather maintained through external social sanction which impels. Impulsion is, in the field of communal mores, a foil to legal compulsion on the one hand and moral conscience and conviction on the other. Communal mores emanate from social intercourse and interaction and therefore imply:

* social status, i.e. a particular stand in the community;

* collective persuasion or impulsion, and

* social acceptance.

Putting law at the one end of the spectrum and morality at the other, the differences (and similarities) between law, morality and communal mores can be presented diagrammatically as follows: 
Reflecting on law, morality and communal mores

\begin{tabular}{lll}
\hline LAW & COMMUNUAL MORES & MORALITY \\
\hline $\begin{array}{l}\text { SECURITY-IN-OFFICE } \\
\text { BY AGREEMENT }\end{array}$ & $\begin{array}{l}\text { RESPONSIBILITY } \\
\text { VOLUNTARY }\end{array}$ & RESPONSIBILITY \\
\hline Authenticated status & Social status & Individual disposition \\
\hline $\begin{array}{l}\text { Normativity, regula- } \\
\text { rity, compulsion-in- } \\
\text { store }\end{array}$ & $\begin{array}{l}\text { Collective persuasion } \\
\text { or impulsion }\end{array}$ & $\begin{array}{l}\text { Interpersonal } \\
\text { persuasion }\end{array}$ \\
\hline Order & Social acceptance & Reliability, troth \\
\hline
\end{tabular}

It is not necessarily 'the majority of the people' who determine what communal mores are. The influence exercised by individuals and institutions to help determine them depends on the status these determining agents enjoy in the broader community which, in turn, accounts for the extent of persuasion which they can exert to win social acceptance for their ideas. It is, therefore, not simply a matter of 'counting heads'. And what emerge in the end as communal mores may - and will most probably - not be acceptable to every individual in terms of his or her personal moral convictions.

Communal mores are susceptible to change, so that the boundaries between them and legal norms keep on shifting - at least within certain confined limits. These limits enclose a grey area. It is often therefore no easy task to determine what communal mores at a given point in time comprise. This holds, in particular, for those mores bordering on law on the one hand and morality on the other.

The more stable and settled a society, the larger the 'operational area' of communal mores, and the smaller the area in which legal compulsion needs be invoked. Following from this: the smaller the area in which legal compulsion is invoked, the larger the area for moral choice. An increase in the area of moral choice is therefore inversely proportional to an increase in the area of legal compulsion, but directly proportional to an increase in the area of communal mores. However, in societies where communal choice holds sway over personal choice, an increase in the area of communal mores does not necessarily extend the area of personal moral choice. In such societies 
collective impulsion is inclined more to normative compulsion rather than interpersonal persuasion. In complex, differentiated or 'open' societies, on the other hand, the tendency is very much the opposite.

The State is the most formal and official institution of authority in a differentiated society. It is furthermore charged with the primary responsibility to keep up a public order of law within its particular territory. It is for this reason that, in a complex and differentiated society, it is regarded as improper for the State as a public institution to make moral choices which can best be made at a personal or an individual level. There are other social institutions which can educate the individual to make moral choices of a certain kind: the family, the church etc. But a State bent on promoting the moral convictions of only a certain segment or segments of its population, does not exercise its authority in the public interest.

On the other hand the State is bound to interpret communal mores as best it can. It is also its duty to continuously 'inspect' the shifting borders between law and these mores, so as to determine the need for either the deregulation of or further official involvement in certain matters.

\section{THE LEGAL PROTECTION OF PRE-NATAL LIFE}

Life cannot be defined scientifically or philosophically. It is one of the fundamentals perhaps the fundamental - of human existence. Other such fundamentals are freedom, justice, love, grace etc. For centuries now scholars and philosophers have tried to define these fundamentals - without success. Fundamentals can at most be recognized ${ }^{2}$ at the level of intuition, i.e. accumulated experience.

Law protects life. What has appeared to be impossible for philosophers and scholars, must therefore be attempted in the field of law: life must be defined in order to protect it. A juridical definition of life can at best be an operational definition which cannot claim any ultimacy (Platt, 1976:10-11). The most it can say is: "This is how life is understood for purposes of its legal protection.' An operational definition must of course correspond as closely as possible to the 'reality' which it defines - even though it cannot purport to be exhaustive.

The law does not define life as such. It has its own operational definition of birth ${ }^{3}$ and

\footnotetext{
2 And not perceived as e.g. the essence of modes of being.

${ }^{3}$ The legal requirements for birth are the following:
} 
it accepts medical opinion as authoritative testimony of the advent of death. ${ }^{4}$ Life then for purposes of the law, will be regarded as the period between birth and death.

Pre-natal life is not defined either. A foetus is taken to be 'live' - for purposes of the statutory offence of abortion - as from the moment the ovum is fertilized ( $S$. $v$ Collop, 1981 (1) S.A. 150 (A) 163G-H; Lupton, 1988:207). The question whether a foetus was alive in a particular instance, will be decided with reference solely to medical opinion. Note that neither 'quickening' of the foetus nor a certain lapse of time after fertilization is required before, in law, a foetus is considered 'alive' (Hunt, 1970:313). 5

In South Africa it is generally accepted that pre-natal life is an 'interest' worthy of legal protection. Its destruction by way of abortion procured through human intervention is a crime (see section 10(1) read with sections 1,3(1)(a)-(d), 5 and 6(1) of the Abortion and Sterilization Act 2 of 1975) 6 except in the following circumstances:

- The foetus/child must be separated from the body of the mother (it is not required that the umbilical cord must have been cut)

- The child must have lived after separation - if only for a moment.

- Some authors also add that the child must have been viable, but there is no general agreement as to this requirement.

See in general Barnard, Cronje \& Olivier, 1986:9-10; Boberg, 1977:8-9;

Van der Vyver \& Joubert, 1985:62-64.

4 Traditionally death is associated with the cessation of the functions of the brain (somatic death) as manifested in the cessation of the vital functions of the heart and lungs. This traditional view has, however, become problematic. It is now possible to sustain the function of the heart and the lungs even after the brain has ceased to function.

See in general Barnard, Cronje \& Olivier, 1986:22-23; Boberg, 1977:22-24; Van der Vyver \& Joubert, 1985:418-420 and Du Plessis, 1976:13-14.

5 In Roe $v$ Wade 410 U.S. 113 (1973) the United States Supreme Court held that a mother has a right to abortion up to the stage when the foetus becomes viable, i.e. normally after 28 weeks of pregnancy but in favourable circumstances as early as 24 weeks after conception. The court thereby settled the question of the protection of a foetal right to life vis-a-vis a maternal right to abortion, but nevertheless (at 159 of the report) consciously and deliberately refrained from expressing an opinion as to when human life begins.

${ }^{6}$ Abortion is defined in section 1 of the Act as "the abortion of a live foctus of a woman with the intent to kill such foetus". The penalty for the crime of abortion is a fine not exceeding R5 000 or imprisonment for a period not exceeding five years or both such fine and imprisonment section $10(1)$. 
- Where continued pregnancy endangers the pregnant woman's life (section 3(1)(a)) or

* constitutes a threat to her physical (section 3(1)(a)) or

* mental health (section 3(1)(b))

* Where there is a serious risk that the child to be born will suffer from a physical defect or

* a mental defect of such a nature that it will be irreparably seriously handicapped (section 3(1)(c))

* Where the foetus has allegedly been conceived as a result of rape ${ }^{7}$ or

* incest (section $3(1)(\mathrm{d}))^{8}$ or

" intercourse outside wedlock ("illegitimate carnal intercourse" - see the definition in section 1) "and the woman is, due to a permanent mental handicap or defect unable to comprehend the consequential implications of or bear the parental responsibility for the fruit of coitus" (section $3(1)(e)$ ).

A lawful abortion can only be procured subject to compliance with a number of rather strict requirements (see in general sections 3 and 6 ).

The attitude of South African jurists to existing abortion laws vary. On the one hand there are those who think that the Act goes too far in decriminalizing abortion. ${ }^{9}$ On

\footnotetext{
${ }^{7}$ Snyman (1984:39)1 points out that, strictly speaking, only a woman who has been raped by a person who can be held criminally responsible for his conduct, will be entitled to an abortion. If the 'rapist' cannot be held criminally responsible for his actions, carnal intercourse with a woman without her consent does not amount to 'rape' in its legal sense and therefore in the sense in which it is uscd in the section. This state of affairs is untenable ("as far as the woman is concerned, the man's mistake is irrelevant") and Snyman suggests an amendment of the relevant provision so as to allow for a lawful abortion in these circumstances.

8 Incest is defined in $\mathbf{s} 1$ of the Act as "carnal intercourse between two persons who are related to each other and by reason of such relationship incompetent to marry cach other". This definition does not refer to incest as a crime (only) and the problem which exists with respect to rape can therefore not arise with respect to incest - Snyman, 1984:391.

${ }^{9}$ Bertrand (1978:277) for example writes:

"In the light of medical knowledge about the development of foetal life and the diminishing number of actual medical indications for abortion, liberal abortion is discrimination against unborn children on the grounds of age, size or shape. The South African Abortion Act, although relatively conservative, cmbodies an attack on the sanctity of human life. By what valid standards can the process be stopped, so that this discrimination is not (logically) extended to apply also to people after birth? Once the sanctity of human life is degraded, society stands at the top of a slippery slope that could lead to abortion on demand (of the mother), voluntary mercy killing (at the request of the patient), abortion on command (of the State), obligatory mercy killing of handicapped pcople (a scientific inquisition), and, ultimatcly, with increasing
} 
the other hand there are those who advocate a so-called liberalization of abortion legislation in South Africa so that medically safe abortions will be available more freely - and perhaps even on demand (Kunst \& Meiring, 1982:264-266). There are also a variety of views in between. ${ }^{10}$

Public opinion in South Africa seems to favour lawful abortion on the grounds presently provided for by the Act and is against abortion for socio-economic reasons (Venter, 1981:131-141). According to Kunst \& Meiring (1982:264), however, the results of certain opinion surveys seem to indicate support for the 'liberalization' of abortion legislation.

\subsection{The Rall-case}

In the case of Christian League of Southern Africa v Rall, 1981 (2) S.A. 821 (O) the question arose whether a threatening infringement of the right to life of a foetus can be prevented by obtaining (on its behalf) an interdict averting or reducing the threat. In normal circumstances a person 'comes into being' for purposes of the law - i.e. becomes a legal subject - at birth. The rule nasciturus pro iam natu habetur quotiens de commodo eius agitur ('the unborn is taken to have been born if it would be to its advantage') is a common law measure predating a person's legal subjectivity to the date of conception. One of the questions that had to be answered in the Rall case was whether this rule provides a legal basis for protecting the life of a nasciturus.

The respondent, a Miss Rall, sought an abortion in terms of section 3(1)(d) of the Abortion and Sterilization Act (supra) alleging that her pregnancy had resulted from rape. The applicant in the matter, the Christian League of Southern Africa, approached the court for the appointment of a curator ad litem, who could represent the foetus in all matters relating to the abortion sought by the respondent. As an organization

technology and totalitarianism, to a socio-political inquisition whereby an elite in society will have complete authority and control over our very life and lives" (also see Van Zyl, 1979:134141).

\footnotetext{
${ }^{10}$ Lupton for example (1985:99; also see 1988:197-215) argues that there is no difference in principle between a newly created embryo on the one hand and a separate sperm and ovum on the other. There should therefore be no legal impediments to destroying such an embryo. He does not advocate abortion on demand though, but nevertheless foresees that once the artificial womb will be perfected, non-foetocidal termination of pregnancy on demand should be allowed during the first trimester of pregnancy. The foetus can then be placed in the artificial womb and allowed to develop fully until the time of its 'birth'.
} 
promoting Christian faith, morals and ethics the applicant further alleged that it had an interest in the matter since its objects included, amongst others, the protection of human life. The court refused the application with costs for in essence the following three reasons:

- The applicant could not convince the court that it had an interest in the matter and, at any rate, the conduct which the respondent sought to interdict was not unlawful.

* The 'nasciturus fiction' does not confer legal subjectivity on the foetus. ${ }^{11}$

* Finally, in relation to the question of a curator ad litem, the court concluded that at any rate the Abortion and Sterilization Act (supra) itself provides for procedures (and for criminal sanctions) which adequately protect a foetus. There is therefore no need for the appointment of a curator ad litem to represent the foetus in proceedings aimed at aborting and destroying it.

F.C. Steyn J's judgment evoked interesting and directly conflicting comments (see for example Bedil, 1981:462-466; Davel, 1981:361-363; Van der Vyver, 1981:305-314; Verster, 1981:153-164). Davel (1981:363) acclaimed the court's hardly disguised hint at the meddlesome in society. Van der Vyver (1981:305), on the other hand, made a scathing attack on what he regarded as the court's subversion of Christian morality.

\footnotetext{
${ }^{11}$ L.C. Steyn, J. inter alia relied on an opinion expressed by Hahlo (1974:73-83) that in South African law "the child in the womb" has no "right to life which can be enforced by its father, in his capacity as its (future?) natural guardian or amicus appointed by the court" (1974:75).

Jurists are not agreed on the real nature of the protection which the nasciturus doctrine affords, some referring to it as a fiction while others call it a rule. The fiction proponents argue that through the application of the doctrine the birth of an unborn child is predated fictitiously to the time of its conception. No real legal subjectivity is, according to this vicw, conferred on the nascitunus bcfore its birth, and its rights and interests are said to be potential: they are kept in abeyance until the time of birth (Barnard, Cronjé \& Olivier, 1986:12-13; Smit, 1976:212-213 and 360-361).

On the other hand therc are those who maintain that the application of the nasciturus rule actually amounts to predating the legal subjectivity of the foetus and that the rights and interests which are protected in the period between conception and birth are real. Accordingly there is, so it is argued, no nced for a fiction (Van der Vyver \& Joubert, 1985:68-69 and Van der Vyver, 1984:8).

The judgment of L.C. Steyn, J. in the Rall case endorses the former view while the latter view is compatible with the notion of protection of pre-natal life.
} 
The Rall judgment can be criticized on legal grounds. ${ }^{12}$ I do not want to deal with these at great length. Just two observations:

\title{
5.1.1 Refusal to extend the nasciturus rule
}

The court justifies its refusal to extend the nasciturus rule to instances where the protection of pre-natal life is sought in inter alia the following terms:

\begin{abstract}
Waar die ongebore vrug nie lewend gebore word nie is daar geen sprake van enige regte wat hom toeval nie en kleef geen regte aan hom, op grond waarvan gesé kan word dat hy 'n regsubjek is nie ... Waar die ongebore vrug se 'regte' met hom sterf, is daar ook geen ruimte vir die uitbreiding van die nascirurus-fiksie tot die beskerming teen vrugafdrywing nie (830A-B).
\end{abstract}

\subsubsection{Requirements for the application of the nasciturus rule}

Usually the application of the nasciturus rule is made subject to the following three requirements:

* Predating legal subjectivity must be to the advantage of the person concerned.

- Such advantage must have accrued after the date of conception.

* The beneficiary must eventually be born alive.

The dictum refers to the second requirement above.

The court's line of reasoning in this regard has prompted Verster (1981:155-159) to argue as follows:

* The 'nasciturus fiction' protects the rights of the foetus conditional upon its eventual birth.

* At birth its legal subjectivity is accordingly predated to the moment when the benefit actually accrued.

- Should the appointment of a curator ad litem be premised on legal subjectivity, a nasciturus who is to be aborted and killed, can never become entitled to the services of a curator, since its chances of being born alive are destroyed.

\footnotetext{
${ }^{12}$ I am in no way suggesting that legal and other objections (e.g. moral objections) can and should be seen in isolation from one another.
} 
I agree with Van der Vyver (1981:306) that this argument comes close to implying that since a person who is murdered loses his or her legal subjectivity and can therefore not enforce any rights against the murderer after the murder, it is also impossible for the victim to take preventive measures against the murderer before the murder.

\subsection{Protection and rights of the unborn}

Verster (1981:159-162) correctly points out that the court in refusing to appoint a curator ad litem disregarded the well-established practice of our courts to appoint curatores ad litem in matters which concern the unborn - sometimes even prior to conception!13 He makes extensive reference to cases dealing with the protection of proprietary rights and interests of the unborn. Ex parte Bester, 1951 (1) S.A. 774 (T) is a telling (and in the present context also to the point) example. In this case the court ordered the appointment of a curator ad litem to represent an unborn child in proceedings where the annulment of the marriage of its mother was sought. The court held that the child to be born had an interest in the matter, since setting aside the mother's marriage, will brand the child illegitimate at birth.

The Rall case will remain a source of controversy since jurists' appreciation of it is bound to be affected by their (varying) views of a matter as fundamental as the true nature and value of human life - albeit pre-natal or 'potential' life. Pivotal to this debate is the question whether legal subjectivity can in certain circumstances come into existence before birth. This question in turn hinges on how a person perceives the nature of 'the human personality' during the various stages before birth.

$\mathrm{Be}$ it as it may, the protection of foetal life is not only a matter of making a moral choice. It is also incumbent upon the guardians of law and order in society: pre-natal life is an interest worthy of legal protection. A State involving itself in the protection of unborn life is not meddling in the private affairs of its citizens. Nor is it making moral choices which can best be made at a personal level. It is protecting life which is its legal duty - a duty which, with due respect, was not adequately observed by the court in Rall's case. My observations in this regard are of course based on an own - I would suggest distinctly Christian - view of the nature of life as such and pre-natal life in particular. Let me elaborate.

Life is not simply a clinical phenomenon. It is true that, since no universally conclusive

${ }^{13}$ Van der Vyver (1981:310-311) strongly supports this contention. 
definition of life exists, the law and other disciplines availing themselves of their own working definitions of life (see above), have to rely heavily on medicine to assist them in establishing the presence or absence of life in particular instances. From this it does not necessarily follow that clinical definitions of life are either impeccably reliable or final. On the contrary, they are working definitions too. They focus on one or two aspects of life only: its biological and perhaps its psychological dimension. ${ }^{14}$ Life, however, comprises more than an interplay of biological and psychological processes: it is the nodal point of our very being in its totality. It ties the human being to a diversified reality. To breathe, to eat, to feel and to have a heartbeat, is to live. To earn a living, to enjoy beauty, to create culture, to be involved in social relationships, to love and be loved and to worship is to live too. And to be secure in doing all these things, to be vouched for, is the right of every human being. It is a basic right, a right pertaining to the nodal point of all these things: to life itself. At this level of security the law comes in - and it has a duty to step in.

What about pre-natal life? Is it not also much more complicated than the biological functions of a foetus? Has the foetus not got an own standing in (for example) the family into which it is to be born? Does it not have an own way of communicating with the outside world - albeit through the medium of its mother, who at any rate fulfils a major role in assisting the maintenance of its vital functions? Potentiality or expectation is characteristic of foetal life. Birth is the fulfilment of one of the most vital expectations of the foetus. With the post-natal human being the element of potentiality, however, remains - vividly so at infancy and perhaps less salient in old age. Birth is not the beginning of life; it is simply a far-reaching change in lifestyle.

Clinical evidence bears out what has just been said. As medical knowledge of the foetus increases, its individuality and humanness becomes increasingly obvious, from a very early stage of its development.

The law must take account of all of this - not only of medical facts about the foetus, but also of pre-natal life as a mode of being in its fullness. The law must vouch for the foetus since it is called upon to vouch for people, for human beings. There is no

\footnotetext{
${ }^{14}$ Levenstein (1988:11-17) and Kriel (1986) both point out that conventional medicine draws on the assumptions of Descartes and Newton that the world and humans in it function as mere machines. The human being is therefore seen as an organism comprised of various parts which function like the parts of a machine. Life, then, would begin when the machine starts functioning properly (and that is controversial) and it would end when the machine stops functioning (and that is controversial too). At any rate, any definition of life (or death) bascd on these assumptions, are bound to be one-sided and, for that reason, inaccurate and inadequate.
} 
difference in principle between criminalizing murder and culpable homicide on the one hand and abortion on the other. It is rather a matter of degree relative to the development and potential of the human being. Pre-natal and post-natal life are both life and ought to be respected and protected as such. 15

The South African law relating to the protection of unborn life is nevertheless seriously deficient in mainly two respects.

First, as stated previously (in 5.1.1 above), there is no reason why in certain circumstances and for private law purposes legal subjectivity cannot be conferred upon an unborn person by virtue of the nasciturus rule. I think that the time has arrived for our courts to settle this matter once and for all and to overrule the patently incorrect judgment of L.C. Steyn J in Christian League of Southern Africa v Rall (supra).

In the second place the situation which arose in the Rall case highlights the need for reform of our abortion legislation in general. Given the nature of pre-natal life, I am uneasy about some of the grounds on which a lawful abortion can be procured, particularly those going beyond necessity and making it possible for one human being to sit in judgement on the quality of life of another ... who cannot defend itself. ${ }^{16}$

The Abortion and Sterilization Act should provide for judicial proceedings in each instance where an abortion on anyone of the grounds provided for is sought. The person seeking the abortion should be required to bring an application to either a court of law or a specialist tribunal. Provision should be made for the automatic appointment of a curator at litem to look after the rights and interests of the unborn child in the course of such proceedings. The proceedings should be adversary in nature and the curator should have the right to cross-examine witnesses. This is the least the law can do to recognize the personality of the unborn child in the process of making a decision which goes to the root of its continued existence.

\footnotetext{
${ }^{15}$ The law of course operates within certain limits and it must often confess its own powerlessness to cater for all situations. It can for instance hardly protect a pre-implantation embryo. In the normal course of events it will be difficult to prove that an embryo was destroyed as a result of for example, preventing implantation through the use of a intra-uterine device. Normally a significant number of pre-implantation embryos are expelled spontaneously anyway. The capacity of the law to secure life is co-determined by the extent to which a living being is in communication with - and integrated into - its environment. With the pre-implantation cmbryo an adequate degree of communication and integration is wanting.
}

16I share the views of Bertrand which were quoted extensively in footnote 9 above. (I am also aware of the fact that 1 most probably have communal mores 'against' me.) 
Reflecting on law, morality and communal mores

William Mc Fee (quoted by Tripp, 1970:81.5) once said the following about birth:

There is nothing like a start, and being born, however pessimistic one may become in later years, is undeniably a start.

The gist of my argument is that every unborn human being has a basic right to this start. A true liberalization of abortion legislation will have to entail the intensified protection of such a right - not its increased subversion.

\section{CONCLUDING REMARKS}

In $\S 2-4$ above a theoretical model expounding the relationship between law, morality and communal mores was developed. Can this model tell Christians how to help improve the (deficient) South African law regarding the protection of pre-natal life? In a sense it cannot: models simply do not provide final and conclusive solutions to problems, but simply help us understand these problems in terms of an own (in casu: Christian) paradigm. In another sense, however, understanding a problem assists one in opting for an appropriate strategy to tackle it.

We must for instance be aware of the fact that, in order to redress the deficiencies of our law in the long term, communal mores will have to be influenced by swaying public opinion. An awareness of the preciousness of human life and, in particular, pre-natal life, must be instilled into the consciousness of a nation comprised of $70 \%$ Christians.

To achieve this, Christians themselves will have to be credible by being consistent. Hostility to the very notion of human rights - like that displayed in comments on the Report on Group and Human Rights of the South African Law Commission in Die Kerkblad of 13 September 1989 (Anon., 1989:7-8)17 - or indifference to human rights issues in general, are for instance inconsistent with a genuine (and moreover credible) concern for the rights of the unborn.

The maturity and, indeed, 'morality' of a legal system become visible in its protection of the rights and interests of the socially weak and vulnerable. The need for such 'special' protection is underscored on several occasions in the Old Testament too. Pre-

\footnotetext{
${ }^{17}$ It should, however, be pointed out that the compatability of the notion of human rights with Christian faith, is currently endorsed by most Christian (and reformed) denominations throughout the world - sce e.g. R.E.S., 1983. The comments in Die Kerkblad, therefore, reflect the concerns of a reactionary minority rather than Christians in general.
} 
natal life is the most vulnerable form of human life, and its protection therefore calls for a special effort. It is ironic that so many 'civilized' legal systems, professing to be bent on the meticulous protection of the rights and, in particular, the right to life of 'post-natal' individuals, are so obviously slack in vouching for foetal life, the most vulnerable form of human life. Some legal systems even play an active and decisive role in facilitating its destruction!

It is equally ironic that in South Africa Christians who profess to respect the sanctity of human life and who hold strong views with respect to the protection of pre-natal life, vociferously defends a system threatening and oppressing socio-politically vulnerable forms of life. Granted, Die Kerkblad's fulmination against the idea of human rights can hardly pass as representative of mainstream Christian-reformed thinking on human rights. It is rather (and at most) a distinctly narrow, ill-informed and outdated version of 'reformed theology'. However, this is not how people 'from outside' perceive it. They see Christians who what they say today they contradict tomorrow. This is in no way conducive to efforts aimed at enhancing public respect for the sanctity of pre-natal life.

Hardly any issue of life can be said to be 'purely moral'. This, as a matter of fact, holds for all bio-ethical issues. But this does not imply that in the field of bio-ethics no room is left for personal, moral choice. On the contrary, since legal coercion is coercion-instore (see $\$ 2$ above) the vast majority of 'bio-ethical situations' are regulated rather by way of moral choice or communal mores. The law steps in either in instances where these less coercive means of regulation fail or where there is a need for defining the status of people (or people-to-be) at a basic level. Personal responsibility is therefore never excluded.

John F. Kennedy once said that "the protection of our rights can endure no longer than the performance of our responsibilities" (Tripp, 1970:804.10). My rights are in other words secure to the extent that I assume responsibility for the rights of others especially the weak and the defenseless. In a society where the rights of the weak are readily trampled on, it is easy for anyone to become one of the weak ... involuntarily. This is worth remembering - even if only for purely pragmatic reasons.

\section{BIBI IOGRAPHY}

ANON. 1989. Handves vir menseregte - is dit Bybels verantwoord? Die Kerkblad, 92(2826):7-8.

BARNARD, A.H., CRONJE, D.S.P. \& OLIVIER, P.J.J. 1986. Die Suid-Afrikaanse persone- en familiercg. Durban : Butterworths. 
Reflecting on law, morality and communal mores

BEDIL, Susan 1981. Can a foetus be protected from its mother? South African Law Joumal, 98(4):462 466.

BOBERG, P.Q.R. 1977. The law of persons and the family. Cape Town : Juta.

DAVEL, Trynie 1981. Christian League of Southern Africa v Rall 19812 SA 821 (O). De Jure, 14(2):361363.

DOOYEWEERD, H. s.a. Encyclopaedie der rechtswetenschap, vol. II. Amsterdam : Bureau Studenteraad Vrije Universiteit (quoted as Encyclopaedic).

DOOYEWEERD, H. 1969. A new critique of theoretical thought, vol. II. Presbyterian and Reformed Publishing Company.

DU PLESSIS, L.M. 1976. Vraagstukke rondom die lewe juridies besien. C.H.E., Series F, I.A.C.

DU PLESSIS, L.M. 1978. Die juridiese relevansie van Christelike geregtigheid. Potchefstroom. (Proefskrif (LL.D) - PU for CHE.)

HAHLO, H.R. 1974. Nasciturus in the limelight. South African Law Joumal, 91(1):73-83.

HUNT, P.M.A. 1970. South African criminal law and procedure, vol. Il. Cape Town : Juta.

JOUBERT, W.A. 1963. Pinchin \& Ano., N.O. v Santam Insurance Co., Ld., 1963 (2) S.A. 254 (W) Tydskrif vir Hedendaagse Romeins-Hollandse Reg, 26:295-296.

KUNST, J. \& Meiring, R. 1982. Abortion law - a need for reform. De Rebus, 1982(198):264-266.

KRIEL, J.R. 1986. Removing medicine's Cartesan mask: The problem of humanising medical education. Unpublished Paper delivered at a Conference of the CMF in Bloemfontein.

LEVENSTEIN, J.H. 1988. Family medicine and the new science. SA Family Practice, 9(1):11-17.

LUPTON, M.L. 1985. Does the destruction of a blastocyst constitute the crime of abortion? South African Law Joumal, 102(1):92-102.

LUPTON, M.L. 1988. The legal status of the embryo. Acta Juridica, 1988:197-215.

PLATT, R.M. 1976. The I-opener: An introduction to philosophy. Englewood Cliffs : Prentice-Hall

RAWLS, J. 1972. A theory of justice. Oxford : Clarendon Press.

R.E.S. 1983. Testimony on human rights. Grand Rapids : Reformed Ecumenical Synod.

SMIT, P.C. 1976. Dic posisie van dic ongeborene in die Suid-Afrikaanse reg met besondere aandag aan die nasciturus-leerstuk. Bloemfontein. (Dissertation - (LL.D.) - U.O.F.S.)

SNYMAN, C.R, 1984. Criminal law. Durban : Butterworths.

STOKER, H.G. 1967. Oorsprong en rigting I. Kaapstad : Tafelberg.

TRIPP, Rhoda Thomas 1970. The International Thesaurus of Quotations. Penguin Books.

VAN DER VYVER, J.D. 1981. Christian League of Southern Africa v Rall 19812 SA 821 (O). Tydskri vir Hedendaagse Romeins-Hollandse Reg, 44(3):305-314

VAN DER VYVER, J.D. 1984. The right to life of the unborn in South African law. (In Kahn, E. ed. The sanctity of human life. Johannnesburg : University of The Witwatersrand Senate Special Lectures 1983. 6-12.)

VAN DER VYVER, J.D. \& JOUBERT, D.J. 1985. Persone- en familiereg. 2nd ed. Cape Town : Juta.

VENTER, J.D. 1981. Die houdings van en houdingsveranderings by blanke Suid-Afrikaners ten opsigte van aborsie. Humanitas, 7(2):131-141.

VERSTER, MARIUS 1981. 'n Foetus, vrugafdrywing en 'n kurator ad litcm. Obiter, 1981:153-164. 


\section{LAWS}

Abortion and Sterilization Act 2 of 1975

\section{COURT CASES}

Christian League of South Africa v Rall 1981(2) S.A. 821 (0)

Ex parte Bester, 1951 (1) S.A. 774 (T)

Roe v Wade 410 U.S. 113 (1973)

S. v Collop, 1981 (1)S.A. 150(A) 163. H 
